\title{
The Shifting Boundaries of Elite and Tabloid Media in Political Sex Scandals
}

\section{Väliverronen, Esa Tapani}

Routledge

2019

Väliverronen , E T \& Juntunen , L J 2019 , The Shifting Boundaries of Elite and Tabloid Media in Political Sex Scandals . in H Tumber \& S Waisbord (eds), The Routledge Companion to Media and Scandal ., 17 , Routledge Media and Cultural Studies Companions, Routledge, London, pp. 174-182.

http://hdl.handle.net/10138/321360

other

submittedVersion

Downloaded from Helda, University of Helsinki institutional repository.

This is an electronic reprint of the original article.

This reprint may differ from the original in pagination and typographic detail.

Please cite the original version. 


\title{
THE SHIFTING BOUNDARIES OF ELITE AND TABLOID MEDIA IN POLITICAL SEX SCANDALS
}

\author{
(draft version on the article published in Tumber, H. \& Waisbord, S. (eds.) (2019). The Routledge \\ Companion to Media and Scandal. London: Routledge, pp. 174-182) \\ https://www.routledge.com/The-Routledge-Companion-to-Media-and-Scandal/Tumber- \\ Waisbord/p/book/9780815387596
}

\begin{abstract}
Intimate revelations of politicians' private lives have become a recurring feature of political journalism across advanced industrial democracies since the 1990s. Since the Clinton-Lewinsky case, political sex scandals have become a global phenomenon, although national differences in conceptions of private and public still seem to exist.

In this chapter, we concentrate on political sex scandals, which are typically revelations of extra-marital affairs and unwanted intrusions into areas of personal domain that politicians want to remain private. Often these include information that might damage a politician's reputation and career.

The focus is on the dynamics between different media in the revelation of political sex scandals. We argue that such scandals, although justified in the name of the public interest, have the effect of softening the professional boundaries between different types of media outlets and creating greater coherence in the field. At the same time, professional norms serve as boundary markers (Singer 2015) as the hierarchy of genres is being renegotiated and the borders between "hard" and "soft" forms of journalism are being redrawn.
\end{abstract}

\section{National differences in exposure}

Research from different countries have pointed at the trend of an increased proclivity of certain media to intrude into the private lives of politicians. However, the intimization process is uneven and by no means universal: politicians' personal lives receive publicity in most countries but to different extents. For example, Castells (2004) has noted that, when it comes to the reporting of extra-marital sex lives, the USA stands at one extreme in its lack of reverence, with continental European democracies at the other, and the UK somewhere in between.

Stanyer $(2013,160)$ confirms that there has been a marked divergence from the 1990s onwards in how much the media are willing to intrude into the private lives of politicians and in the extent to which revelations about politicians' sexual relations and orientation flood the public sphere in different countries. ${ }^{1}$ Based on a comparison of seven countries in 1990-2009, the non-consensual exposure of politicians' infidelity was largely a phenomenon of the USA, and to some extent the UK, but almost absent in the studied continental European countries (France, Germany, Italy, and Spain).

Traditionally, politicians' sexual misdemeanors have been very much a taboo in many European countries. For example, in France, politicians have enjoyed strong privacy protection and the extra-marital affairs of leading politicians have been public secrets, unlikely to cause much turmoil. In Germany, too, there has been a tacit agreement that journalists do not disclose private details about politicians' marriage problems, extra-marital affairs, and sexual inclinations (Esser and Hartung 2004, 1064-1065).

However, the zone of privacy around politicians is said to be shrinking also in those countries where they have traditionally enjoyed greater privacy protection. Authors have remarked on the personalized nature of political communication in Italy (Campus 2010), Germany (Holtz-Bacha 2004; Neckel 2005), and France (Kuhn 2004; 2007), although intimization has never gained as intrusive a dynamic as in the USA, where even unsubstantiated rumors about politicians' extra-marital affairs routinely make it to the news (Sabato et al. 2000, 71), or in the UK, where intrusions into the private lives of politicians have been normalized in the tabloid press since the 1990s (Deacon 2004).

So why have sex scandals attracted more public attention in some countries than in others? International research suggests that the occurrence or absence of political sex scandals is not attributable to mono-causal explanations, but rather the outcome of a combination of different political, legal, media-related, and sociocultural conditions (see Thompson 2000, 147-148; Stanyer 2013, 100).

Part of the reason lies in differences in political culture and legislation. According to Stanyer (2013, 78), politically related conditions include, for example, greater emphasis on character and the growing legal control of political life. These factors have been apparent particularly in the USA. Also, the levels of press-party parallelism in the different countries might help explain the differing cultures. 
The presence or absence of legal protection for politicians' privacy also plays an important role. Intrusions are reportedly more likely in countries where the boundaries of the private have no legal recognition. For example, France and Germany provide public figures with a high degree of legal privacy protection, while the UK, for instance, has no specific law against invasions of privacy (Frost 2000, 125). Although the USA does have a privacy law, it excludes politicians from essential parts of it and the US courts tend to accept the media's definition of newsworthiness (Christians et al. 2005, 106; see also Esser and Hartung 2004, 1064).

Another factor that needs to be considered is the ethical consensus on the appropriateness of exposure, often expressed in the professional codes of conduct (Stanyer 2013, 83-88). In some journalistic cultures, particularly in Europe, private is separated from public in matters of sex and, thus, intrusions into politicians' private lives are considered amongst media professionals not just potentially illegal but also ethically inappropriate unless there is a strong public-interest motive.

In Finland, used as an exemplary case in this chapter, both the constitution and criminal law provide protection for privacy. However, the law says that the dissemination of information about a person's private life is permitted if and to the extent that this is necessary for the balanced treatment of a matter of social interest. The "Guidelines for Journalists" state that particularly sensitive matters about a person's private life "may only be published with the consent of the person in question, or if such matters are of considerable public interest." This has subsequently been complemented with a three-tiered classification of degrees of privacy protection depending on the amount of power wielded by the person: the more power they have, the less privacy protection is provided. ${ }^{2}$

The media-related conditions include commercial pressures and the tabloidization of the media. The tabloid media, with a focus on celebrities' personal lives, are more likely to intrude into politicians' private lives than other types of media (Stanyer \& Wring 2004) and thus intimization is more of a feature in countries where there is a strong celebrity tabloid media and more competition between such media outlets-most notably in the USA and the UK.

Finally, it has been suggested in previous research that different social norms might be a possible explanation for the absence or presence of political sex scandals. In some socio-cultural conditions, infidelity is seen as a private matter, while in others it is considered something of a public interest. Also, in some societies disapproval of infidelity has been interpreted as being more entrenched, while in others attitudes towards extra-marital affairs are more relaxed.

According to Stanyer's (2013, 91-94) findings, the high levels of exposure are best explained by the combination of large tabloid presences and what he calls "a weak privacy culture," that is a lack of legal privacy protection for political elites and a weak consensus on privacy amongst journalists. In addition, the social conservative agenda of the Christian right seems to explain the high levels of publicized infidelity in the USA, while the strong presence of intensely adversarial politically aligned press plays a role in the UK (see also Downey and Stanyer 2013).

\section{The Finnish case: The symbiosis of news media, tabloids, and gossip magazines}

Previous research has pointed to the role of "critical events" in marking a point of change (Stanyer 2013, 22-23; see also Splichal \& Garrison 2000; Summers 2007). The Clinton- Lewinsky scandal is a good example of such an event. US journalists used to be less willing than their British counterparts to publish allegations of sexual affairs for a good deal of the twentieth century, but this has changed considerably during the last decades (e.g. Tumber 2004, 1125-1126; Summer 2007).

Similar junctures can be found in other countries too. In Finland, there are two high-level sex scandals that marked a change in conventions in the journalistic orientation towards politicians' private lives, destroying the gentleman's agreement that previously marked political reporting. The first case revolved around sex allegations concerning Finnish Prime Minister Matti Vanhanen in 2005-2009. The second case was a text messaging scandal, which led to the resignation of Minister of Foreign Affairs, Ilkka Kanerva, in 2008 (Juntunen \& Väliverronen 2010).

The intimate life of politicians was long a taboo subject in Finnish journalism and, before the twenty-first century, virtually all political scandals in Finland had to do with the exercise of political and economic power. A comparative study shows that political sex scandals began to emerge also in other Nordic countries in the early 2000s, though concerning less high-profile politicians than in Finland (Allern \& Pollack 2012).

Prime Minister (PM) Vanhanen's private life first attracted widespread media notice in spring 2005 following his announcement that he was divorcing his wife. Speculation over a highranking politician's extra-marital affairs was something never before seen in Finnish political journalism. In the following years, the gossip magazines and tabloids run several unadulterated scandal stories involving the PM's private life.

The media circus reached its zenith with the announcement by the PM's former lady friend that she was going to write a book about her affair with the PM. Initially the PM's Bride was intended as a compilation of intimate text messages sent by the PM, but these plans were soon dropped, no doubt for fear of legal sanctions. Soon the PM's private life seemed to evolve into a media phenomenon in its own right, receiving routine coverage in the media, including news media. By the time of the book launch attentions began to turn back in on the mass media's collective response to the phenomenon they themselves had created. 
Journalists had several different types of arguments to justify the publication of details about the PM's private life. Firstly, they felt it necessary to ask whether and how the PM's divorce and revelations about his intimate life affected the performance of his duties. Secondly, they raised the question of how the revelations would affect his political image as well as his reliability and credibility as a politician while he had specifically promoted himself as a staunch advocate of family values. Thirdly, the reporting on Vanhanen's private life was justified by reference to the potential political implications of the scandal. It was thought that the revelations about his marital status and sex life might well influence the vote of party members, particularly the more conservative camp, and that it might even have an effect on the political fight between parties.

Previous research has shown that the alleged or apparent hypocrisy of a politician is often considered by journalists as legitimate justification for privacy intrusions. Actions in politicians' personal lives are inevitably compared to their previous public pronouncements and disjunctures between the personal domain and public life, which often generate claims of hypocrisy (see Thompson 2000; Stanyer 2013, 166). Therefore, the media are more eager to expose extramarital dalliances of those politicians that have espoused family values in public but failed to live up to those standards in their personal lives.

The scandal around the Foreign Minister Kanerva - a well-known ladies' man — burst out in Spring 2008 when he was caught with his phone down after sending a couple of hundred text messages to an erotic dancer. Some of the messages were subsequently published by the popular gossip magazine Hymy that squeezed out every drop of the story, keeping it hanging for weeks while carefully weighing the legal risks of publishing before finally releasing the messages. At the peak of the scandal, the country's biggest news media also reported on the case daily, repeating what had already been said several times over.

In Kanerva's case, the main arguments against him were the loss of credibility and the fact that he had first told (white) lies when he was asked about the text messages. This was also not the first time that the Foreign Minister was in the headlines because of his sexting, as he had already been publicly accused twice before for bombarding women with texts. Consequently, Kanerva, who had earlier promised to clean up his act, was sacked from the Cabinet. This was the first time that a Finnish politician was forced to resign over a scandal in his private life.

In both cases, the revelations pushed the politician's career on a downhill slide. PM Vanhanen continued doggedly in his office and as a chair of the Centre Party for a couple of years before temporarily withdrawing from daily politics. In 2015 he was re-elected to the Parliament and in 2018 he joined the presidential elections as the Centre Party's candidate, which resulted in a flop. Kanerva has continued in the parliament and politics but with a less public profile. The old sins came back to haunt him in early 2018 when, contrary to expectations, he was not elected as the President of the Finnish Parliament. According to various interpreters, this was because the elections coincided with the Me Too campaign.

International research shows that the political consequences of sexual revelations vary. Unlike many other countries, in the UK scandals tend to have immediate political consequences, and over the years a number of ministers have been forced to resign over tabloid allegations of sexual misconduct (Tumber 2004, 1128). In the USA, between 1970 and 2009 over half of the elected officials continued in their posts after the exposure of their extra-marital affairs. Of those that resigned, only about 10 percent left politics altogether (Stanyer 2013, 163). Also, studies of public opinion show that sexual infidelity is not necessarily punished by the voters. For example, the Lewinsky scandal did not seem to have a significant effect on Clinton's popularity (Lawrence \& Bennet 2001).

\section{From symbiosis to softening boundaries}

The above-described Finnish scandals serve as examples of the changes sweeping the media landscape. Most allegations started their life in the gossip papers or in the tabloid press and then trickled through to the news media.

We argue that sex scandals have the tendency to nourish a tacit symbiosis between different media. First, relations grew closer between the gossip press and afternoon papers as they competed for new revelations. At this point, most news media outlets opted to keep a safe distance from these sensations and scandals, addressing them after a suitable time lag but still with some reluctance. Gossip magazines were never quoted directly.

Later, the revelations made their way via the afternoon papers into the news media, and the differences across the media field were all but wiped out. The more widely the scandal spread throughout the field, the easier it became for the traditional news media to deal with the subject, as they could always justify their involvement by saying everyone else was discussing it as well. Once the news media got going, they started to make ever more intimate revelations about politicians' private lives.

Williams and Delli Carpini $(2004,1227)$ have, among others, pointed out that a juicy sex scandal is liable to cross media boundaries. Tumber (2004), for his part, notes that a full-blown public scandal requires the involvement of the whole media field; even though sensational media play a key role in stirring up the initial furore, it is only when the rest of the field join in that a true scandal is created. At the same time, the traditional news media are increasingly following the tabloid press news agenda which leads to a prevalence of tabloid entertainment values and a disregard for the traditional principles of reporting (Tumber 2004, 1124-1125). 
Although the peccadilloes may come to public attention through a myriad of media outlets and via different media genres, the tabloid or boulevard press is often at the forefront of the coverage. In this symbiotic relationship, the news media need a gossip press to do the "dirty work," to dig up the sleaze that is the stuff of scandals. While the quality media want to maintain their separation from the sensational press, at the same time gossip magazines continue to provide an increasing supply of interesting storylines of current interest. While using these stories and the same ways of framing them, other media very rarely call into question the practices of the sensationalist press, such as cash payments for new revelations, even though they firmly dissociate themselves from such practices.

We argue that, apart from stirring up debate about the boundary line between the private and public, scandals also have the effect of softening the boundaries between different media and creating greater coherence in the media field (see also Juntunen \& Väliverronen 2010). In the face of outside criticism, the media has stood united. In particular, attempts by some politicians to criticize it for moral bankruptcy were unanimously rejected by appealing to freedom of speech.

The concepts of infotainment, sensationalism, soft news, and tabloidization have been widely used in describing or explaining the shifting boundaries in journalism. Even though the term "tabloidization" has mainly been used as a generic catchword rather than an analytical tool in communications research (Gripsrud 2000), it certainly has application in the analysis of sex scandals as it helps to explain and interpret the trickling down of subjects and story framings from the tabloid press and sensation magazines to news journalism.

According to Otto et al. $(2017,145)$, the process of tabloidization is characterized by "spillovers of values from the popular to the traditional news media." Tabloidization is composed of three dimensions: changes in content (e.g. from political to human interest), changes in form (e.g. towards shorter stories), and changes in the mode of address (e.g. in style and tone towards "street-talk") (ibid.; see also Esser 1999). Thus, tabloidization brings together the dissemination of topics, forms, and styles. Tabloid journalism is mainly interested in topics related to celebrities and their private lives, entertainment, and sports. The stories are typically framed as scandals, revelations about someone's private life, and unfolding narratives.

The softening of boundaries is connected to the stiffening competition among different media that has brought about a convergence of media contents and forced media organizations to keep a closer eye on one another. Usually a key difference between sensationalist tabloid media and quality media has been precisely the way they deal with private life: the private has traditionally been the realm of gossip magazines, whereas news journalism has focused on the public. But these boundaries are now being blurred and the stories circulating in the different media are increasingly all the same.

The general trend towards increasing entertainment in the media has presented a challenge for traditional news media, which has to explain the rationale and reasons for this trend both to their audiences and to the journalistic profession itself. Whereas tabloidization is generally associated with concerns of declining quality, in political sex scandals social importance and people's curiosity shake hands, making them a legitimate subject for any media.

As the wall that used to protect politicians' private life was beginning to crumble, the Finnish journalists were adamant that this marked a change for the better. Traditionally, there has been a close identity between politicians and political journalists in Finland, but these relations were now cooling down. The new generation of journalists especially were openly questioning the customary ways of political news reporting, keen on getting the message across that political journalism was finally baring its teeth.

As for the task of monitoring and controlling the exercise of power, it is symptomatic, however, that the individually oriented scandal approach rarely leads to the identification or questioning of the true underlying problem, such as unhealthy structural dependencies in politics.

\section{The normalization of sex scandals}

Within the past 20 years, scandals surrounding the private lives of politicians have become a somewhat permanent feature of political news around the Western world. What then are the consequences of increased exposure of intimate affairs for politics and political journalism?

In the absence of up-to-date comparative research, it is hard to say exactly how the amount and magnitude of political sex scandals have evolved within the past ten years. On one hand, it seems that in a global news environment national differences have to some extent diminished in the sense that the struggle over privacy is now increasingly transnational. As news flows across borders at ever-increasing speeds and volumes, so also the peccadilloes of top politicians are often recycled into global news. Oehlkers (2000) calls this an "international media echo". The Internet and new media landscape have also eroded public figures' ability to control the flow of personal information because the privacy laws do not stretch beyond state borders.

On the other hand, national differences seem to persist in the extent of exposure. While the Wikipedia ${ }^{3}$ listing of federal sex scandals in the USA shows continuous growth, in many European countries they have been largely absent in recent 
years. Also, few of the major sex scandals of the 2010s have involved high-level politicians-Silvio Berlusconi and Nicholas Sarkozy being the most notable exceptions.

In sum, what we are looking at is not necessarily an inevitable progression towards greater intimization of political journalism; and there are signs of opposite tendencies as well. An interesting question is what the implications of the intimization of political journalism and the shifting of boundaries between different media are for journalism as a profession.

As pointed out by Sjøvaag $(2015,101)$, the boundary between hard and soft news is the dividing line that separates one of the strongest dichotomies in news production, reflecting "the hierarchy that separates the higher and lower forms of journalistic genres, professional practices, ethical issues, and journalism's potential socio-democratic impact." The hierarchy of genres help to reproduce the norms and ideologies of the field that protects journalism from outside threats. While hard news helps to maintain authority in the field, soft news can be interpreted as potentially damaging to the professional ideal (ibid., 101-109).

For traditional news media, the key defense for privacy intrusions in political journalism has been that the exposures are in the public interest (Morrison and Svennevig 2007; Juntunen \& Väliverronen 2010), while reporting politicians' extra-marital sex lives for their own sake has not been considered justified. The primary reason for why political journalists have been generally reluctant to seek out sex stories is their self-conception as professionals (Tumber 2004). When the so-called prestige media first began to see extra-marital lives of politicians as legitimate news stories, the intrusions were often justified by saying that when distancing itself from politicians, political journalism was, in fact, playing out its role as the Fourth Estate better.

However, the public interest argument has perhaps started to lose its explanatory power in the eyes of the profession, as routine coverage of extra-marital dalliances has also become more commonplace in news journalism. If parts of the media are now re-adopting a more reticent attitude towards covering politicians' private lives, as the lack of recent sex scandals in Finland and elsewhere suggests, this may also concern having to face fierce outside criticism.

In the UK, where the amount of political sex scandals is much higher than elsewhere in Europe, the intrusive tactics of the tabloid press have prompted massive public criticism and wide-scale debate on press standards in recent years. The News of the World phone-hacking scandal and the inquiry into it led not only to the closure of the paper but also to the closure of the Press Complaints Commission and there were also promises of further regulatory reform. Whether or not this marked a decline in the exposure of the sex lives of politicians, remains to be seen (cf. Stanyer 2013, 159, and 167).

On the other hand, it will be interesting to see whether the global Me Too movement, that has encouraged women in all sectors to speak out against men who have sexually harassed and abused them, will bring along new cases involving politicians. Thus far, the British Defence Secretary Michael Fallon resigned from his post because of sexual harassment allegations. The European Parliament has also been shaken by a sexism problem that has been rampant for years.

In their interview study on public attitudes in the USA, Wojdynski and Riffe $(2011,218)$ found "a public with increasingly accepting views of media coverage of politicians' private lives” comparing results from 2001 and 2009. When comparing the importance and public acceptance of different public revelations from financial impropriety to substance abuse and sexual infidelity, the last one was considered to be least important. Yet, 55 percent of the respondents agreed that media should cover issues when "the leader has had an extramarital affair with someone of the opposite sex" (ibid., 215) while 35 percent disagreed. Wojdynski and Riffe (220) conclude that although philandering was considered less newsworthy, "it may also be true that coverage of extramarital affairs has become common enough to render it tiresome."

It seems that, as revelations about politicians' private lives have become more commonplace and a part of everyday media life, the outbursts often come and go without major importance or political consequences. In fact, it can be argued that, along with their normalization, the threshold of a major political sex scandal is probably now higher than it was in the first decade of the twenty-first century. The US President Donald Trump is a good example of a politician who is seemingly immune to any kind of scandal, despite the wealth of potentially scandalous events in his past.

The boundaries in journalism are not static but move over time (e.g. Carlson 2015) and, thus, both the borders of the public and private in journalism and the positions on the continuum between the serious and the tabloid are negotiable.

\section{Notes}

1 As defined by Stanyer $(2013,14-15,152)$, "intimization is a revelatory process which involves the publicizing of information and imagery from what we might ordinarily understand as a politician's personal life." It is a process whereby values from the private sphere are transferred to the public sphere (Van Zoonen 1991, 223). As alternatives to intimization, researchers have used other close-by concepts, such as "personalization," "celebrization," or even "privatization" (for a discussion and critique of these concepts see Stanyer 2013, 7-12).

2 Group A comprises influential decision-makers in politics, administration, and business. Group B includes famous figures in contemporary history who are frequently in the public eye, for instance in the field of culture and entertainment. Finally, Group C consists of ordinary citizens. 


\section{References}

Allern, S. and Pollack, E. (2012) (Eds.). Scandalous! The Mediated Construction of Political Scandals in Four Nordic Countries. Gothenberg: Nordicom.

Campus, D. (2010). "The Mediatization and Personalization of Politics in Italy and France: The Cases of Berlusconi and Sarkozy". International Journal of Press Politics, 15 (2), pp. 219-235.

Carlson, M. (2015). "Introduction: The Many Boundaries of Journalism", In Matt Carlson \& Seth Lewis (Eds.), Boundaries of Journalism: Professionalism, Practices and Participation ( pp. 1-18). London: Routledge.

Castells, M. (2004). The Information Age: Economy, Society and Culture, Vol. 2: The Power of Identity (2nd ed.). Oxford: Blackwell.

Christians, C., Rotzoll, K., Fackler, M., Brittain McKee, B. and Woods, R. (2005). Media Ethics: Cases and Moral Reasoning, 7th ed. Boston: Pearson.

Deacon, D. (2004). "Politicians, Privacy and Media Intrusion in Britain", Parliamentary Affairs, 57(1), pp. 9-23.

Downey, J. and Stanyer, J. (2013). "Exposing Politicians' Peccadilloes in Comparative Context: Explaining the Frequency of Political Sex Scandals in Eight Democracies Using Fuzzy Set Qualitative Comparative Analysis". Political Communication, 30 (3), pp. 495-509.

Esser, F. (1999). “Tabloidization of News: A Comparative Analysis of Anglo-American and German Press Journalism.” European Journal of Communication, 14(3), pp. 291-324.

Esser. F. and Hartung, U. (2004). "Nazis, Pollution and No Sex: Political Scandals as a Reflection of Political Culture in Germany", American Behavioral Scientist 47(8), pp. 1040-1071.

Frost, C. (2000). Media Ethics and Self-regulation. Singapore: Longman.

Gripsrud, J. (2000). "Tabloidisation, Popular Journalism, and Democracy”, In Colin Sparks and John Tulloch (Eds.), Tabloid Tales: Global Debates over Media Standards. Lanham: Rowman \& Littlefield, pp. 285-300.

Holtz-Bacha, C. (2004). "Germany: How the Private Life of Politicians Got into the Media", Parliamentary Affairs 57(1), pp. 41-52.

Juntunen, L. and Väliverronen. E. (2010). "Politics of Sexting: Re-negotiating the Boundaries of Private and Public in Political Journalism”. Journalism Studies 11 (6), pp. 817-831.

Kuhn, R. (2004). “'Vive La Différance'? The Mediation of Politicians' Public Images and Private Lives in France”, Parliamentary Affairs 57(1), pp. 24-40.

Kuhn, R. (2007). "The Public and the Private in Contemporary French Politics”, French Cultural Studies, 18 (2), pp. $185-200$.

Lawrence, R.G. and Bennett, W. (2001). "Rethinking Media Politics and Public Opinion: Reactions to the Clinton-Lewinsky Scandal." Political Science Quarterly, 116(3), pp. 425-446.

Morrison, D.E. and Svennevig, M. (2007). "The Defence of Public Interest and Intrusion of Privacy: Journalists and the Public." Journalism, 8(1), pp. 44-65.

Neckel, S. (2005). "Political Scandals: An Analytical Framework", Comparative Sociology, 4 (1-2), pp. 101-114.

Oehlkers, P.W. (2000). "Mediating News: The International Media Echo and Symbolic International Relations", In A. Malek and A.P. Kavoori (Eds.) The Global Dynamics of News: Studies in International News Coverage and News Agenda. Stamford, CT: Ablex.

Otto, L., Glogger, I. and Boukes, M. (2017). "The Softening of Journalistic Political Communication: A Comprehensive Framework Model of Sensationalism, Soft News, Infotainment, and Tabloidization”. Communication Theory, 27(2), pp. $136-155$.

Singer, B. (2015). "Out of Bounds: Professional Norms as Boundary Markers", In Matt Carlson \& Seth Lewis (Eds.), Boundaries of Journalism: Professionalism, Practices and Participation (pp. 21-36). London: Routledge.

Sjøvaag, H. (2015). "Hard News/Soft News: The Hierarchy of Genres and the Boundaries of the Profession", In Matt Carlson \& Seth Lewis (Eds.), Boundaries of Journalism: Professionalism, Practices and Participation (pp. 101-117). London: Routledge.

Splichal, S. and Garrison, B. (2000). "Covering Public Officials: Gender and Privacy Issue Differences.” Journal of Mass Media Ethics, 15(3), pp. 167-179.

Stanyer, J. (2013). Intimate Politics. Cambridge: Polity Press.

Stanyer, J. and Wring, D. (2004). "Public Images, Private Lives: An Introduction”, Parliamentary Affairs, 57(1), pp. 1-8.

Summers, J.H. (2007). "What Happened to Sex Scandals? Politics and Peccadilloes, Jefferson to Kennedy", In N. Negrine and J. Stanyer (Eds.) The Political Communication Reader. London: Routledge.

Thompson, J. (2000). Political Scandal: Power and Visibility in the Media Age. Cambridge: Polity Press.

Tumber, H. (2004). "Scandal and Media in the United Kingdom: From Major to Blair", American Behavioral Scientist, 47(8), pp. $1122-1137$.

Van Zoonen, L. (1991). “A Tyranny of Intimacy? Women, Feminity and Television News”, In P. Dahlgren \& C. Sparks (Eds.), Communication and Citizenship: Journalism and the Public Sphere. London: Routledge.

Williams, B. and Delli Carpini, M. (2004). "Monica and Bill All the Time and Everywhere: The Collapse of Gatekeeping and Agenda Setting in the New Media Environment", American Behavioral Scientist, 47(9), pp. 1208-1230.

Wojdynski, B. and Riffe, D. (2011). "What Kind of Media, and When? Public Opinion about Press 